\title{
Viral RNA load in plasma is associated with critical illness and a dysregulated host response in COVID-19
}

Jesús F. Bermejo-Martin 1,2,3† ${ }^{+}$Milagros González-Rivera ${ }^{4,5 \dagger}$, Raquel Almansa ${ }^{1,2,3 \dagger}$, Dariela Micheloud ${ }^{6 \dagger}$, Ana P. Tedim ${ }^{1,2}$, Marta Domínguez-Gil ${ }^{7 \dagger}$, Salvador Resino ${ }^{8 \dagger}$, Marta Martín-Fernández ${ }^{1,2}$, Pablo Ryan Murua ${ }^{9}$, Felipe Pérez-García ${ }^{10}$, Luis Tamayo ${ }^{1,11}$, Raúl Lopez-Izquierdo ${ }^{12}$, Elena Bustamante ${ }^{13}$, César Aldecoa114,15, José Manuel Gómez ${ }^{16}$, Jesús Rico-Feijoo ${ }^{1,15}$, Antonio Orduña ${ }^{17}$, Raúl Méndez ${ }^{18}$, Isabel Fernández Natal ${ }^{19}$, Gregoria Megías ${ }^{20}$, Montserrat González-Estecha ${ }^{4,5}$, Demetrio Carriedo ${ }^{21}$, Cristina Doncel ${ }^{1,2,3}$, Noelia Jorge ${ }^{1,2,3}$, Alicia Ortega ${ }^{1,2,3}$, Amanda de la Fuente ${ }^{1,2,3}$, Félix del Campo ${ }^{22}$, José Antonio Fernández-Ratero ${ }^{23}$, Wysali Trapiello24, Paula González-Jiménez ${ }^{18}$, Guadalupe Ruiz ${ }^{24}$, Alyson A. Kelvin ${ }^{25,26}$, Ali Toloue Ostadgavahi ${ }^{25,26}$, Ruth Oneizat ${ }^{7}$, Luz María Ruiz ${ }^{7}$, Iria Miguéns ${ }^{6}$, Esther Gargallo ${ }^{6}$, loana Muñoz ${ }^{6}$, Sara Pelegrin ${ }^{15}$, Silvia Martín ${ }^{1,15}$, Pablo García Olivares ${ }^{16}$, Jamil Antonio Cedeño ${ }^{16}$, Tomás Ruiz Albi22, Carolina Puertas ${ }^{4}$, Jose Ángel Berezo ${ }^{1,11}$, Gloria Renedo ${ }^{13}$, Rubén Herrán 1,11, Juan Bustamante-Munguira ${ }^{27}$, Pedro Enríquez ${ }^{11}$, Ramón Cicuendez ${ }^{13}$, Jesús Blanco ${ }^{11}$, Jesica Abadia ${ }^{28}$, Julia Gómez Barquero ${ }^{28}$, Nuria Mamolar ${ }^{13}$, Natalia Blanca-López ${ }^{9}$, Luis Jorge Valdivia21, Belén Fernández Caso ${ }^{19}$, María Ángeles Mantecón ${ }^{20}$, Anna Motos ${ }^{3,29}$, Laia Fernandez-Barat ${ }^{3,29}$, Ricard Ferrer ${ }^{3,30}$, Ferrán Barbé ${ }^{3,31}$, Antoni Torres ${ }^{3,29 \dagger}$, Rosario Menéndez ${ }^{3,18 \dagger}$, José María Eiros ${ }^{7 \dagger}$ and David J. Kelvin ${ }^{25,26^{*}+}$

\begin{abstract}
Background: COVID-19 can course with respiratory and extrapulmonary disease. SARS-CoV-2 RNA is detected in respiratory samples but also in blood, stool and urine. Severe COVID-19 is characterized by a dysregulated host response to this virus. We studied whether viral RNAemia or viral RNA load in plasma is associated with severe COVID-19 and also to this dysregulated response.

Methods: A total of 250 patients with COVID-19 were recruited (50 outpatients, 100 hospitalized ward patients and 100 critically ill). Viral RNA detection and quantification in plasma was performed using droplet digital PCR, targeting the N1 and N2 regions of the SARS-CoV-2 nucleoprotein gene. The association between SARS-CoV-2 RNAemia and viral RNA load in plasma with severity was evaluated by multivariate logistic regression. Correlations between viral
\end{abstract}

\footnotetext{
*Correspondence: dkelvin@jidc.org

†Jesús F. Bermejo-Martin, Milagros González-Rivera, Raquel Almansa, Dariela Micheloud, Marta Domínguez-Gil, Salvador Resino are co-first authors and these authors contributed equally.

${ }^{\dagger}$ Antoni Torres, Rosario Menéndez, José María Eiros, David J. Kelvin are co-last authors and these authors contributed equally.

${ }^{25}$ Department of Microbiology and Immunology, Faculty of Medicine,

Canadian Center for Vaccinology CCfV, Dalhousie University, Halifax, NS B3H 4R2, Canada

Full list of author information is available at the end of the article
}

(c) The Author(s) 2020. Open Access This article is licensed under a Creative Commons Attribution 4.0 International License, which permits use, sharing, adaptation, distribution and reproduction in any medium or format, as long as you give appropriate credit to the original author(s) and the source, provide a link to the Creative Commons licence, and indicate if changes were made. The images or other third party material in this article are included in the article's Creative Commons licence, unless indicated otherwise in a credit line to the material. If material is not included in the article's Creative Commons licence and your intended use is not permitted by statutory regulation or exceeds the permitted use, you will need to obtain permission directly from the copyright holder. To view a copy of this licence, visit http://creativecommons.org/licenses/by/4.0/. The Creative Commons Public Domain Dedication waiver (http://creativeco mmons.org/publicdomain/zero/1.0/) applies to the data made available in this article, unless otherwise stated in a credit line to the data. 
RNA load and biomarkers evidencing dysregulation of host response were evaluated by calculating the Spearman correlation coefficients.

Results: The frequency of viral RNAemia was higher in the critically ill patients (78\%) compared to ward patients $(27 \%)$ and outpatients $(2 \%)(p<0.001)$. Critical patients had higher viral RNA loads in plasma than non-critically ill patients, with non-survivors showing the highest values. When outpatients and ward patients were compared, viral RNAemia did not show significant associations in the multivariate analysis. In contrast, when ward patients were compared with ICU patients, both viral RNAemia and viral RNA load in plasma were associated with critical illness (OR [Cl 95\%], p): RNAemia (3.92 [1.183-12.968], 0.025), viral RNA load (N1) (1.962 [1.244-3.096], 0.004); viral RNA load (N2) (2.229 [1.382-3.595], 0.001). Viral RNA load in plasma correlated with higher levels of chemokines (CXCL10, CCL2), biomarkers indicative of a systemic inflammatory response (IL-6, CRP, ferritin), activation of NK cells (IL-15), endothelial dysfunction (VCAM-1, angiopoietin-2, ICAM-1), coagulation activation (D-Dimer and INR), tissue damage (LDH, GPT), neutrophil response (neutrophils counts, myeloperoxidase, GM-CSF) and immunodepression (PD-L1, IL-10, lymphopenia and monocytopenia).

Conclusions: SARS-CoV-2 RNAemia and viral RNA load in plasma are associated with critical illness in COVID-19. Viral RNA load in plasma correlates with key signatures of dysregulated host responses, suggesting a major role of uncontrolled viral replication in the pathogenesis of this disease.

Keywords: SARS-CoV-2, Cytokine, Sepsis, COVID-19, Plasma, Rnaemia, Viral RNA load, ICU

\section{Background}

With well over 43 million cases and 1.56212 deaths globally, Coronavirus disease 2019 (COVID-19) has become the top economic and health priority worldwide [1]. Among hospitalized patients, around $10-20 \%$ are admitted to the intensive care unit (ICU), 3-10\% require intubation and $2-5 \%$ die [2]. SARS-CoV-2 RNA is commonly detected in nasopharyngeal swabs; however, viral RNA can be found in sputum, lung samples, peripheral blood, serum, stool samples and to a limited extent urine [3-6]. While the lungs are most often affected, severe COVID19 also induces inflammatory cell infiltration, haemorrhage and degeneration or necrosis in extra-pulmonary organs (spleen, lymph nodes, kidney, liver, central nervous system) [7, 8]. Patients with severe COVID-19 show signatures of dysregulated response to infection, with immunological alterations involving moderate elevation of some cytokines and chemokines such as IL-6, IL-10 or CXCL10, deep lymphopenia with neutrophilia, systemic inflammation (elevation of C-reactive protein, ferritin), endothelial dysfunction, coagulation hyper-activation (D-dimers) and tissue damage (LDH) [9-14].

Our hypothesis is that systemic distribution of the virus or viral components could be associated with the severity of COVID-19, and in turn to a number of parameters indicating the presence of a dysregulated response to the infection.

While the SARS-CoV-2 virus has been reported to be difficult to culture from blood [4], PCR-based methods are able to detect and quantify the presence of genomic material of the virus in serum or plasma, representing an useful approach to evaluate the impact of the extrapulmonary dissemination of viral material on disease severity and also on the host response to the infection [5, 15]. An excellent approach for achieving absolute quantification of viral RNA load is droplet digital PCR (ddPCR). ddPCR is a next-generation PCR method, which offers absolute quantification with no need of standard curve and greater precision and reproducibility than currently available qRT-PCR methods, as revised elsewhere [16].

We employed here ddPCR to detect and quantify viral RNA in plasma from COVID-19 patients discharged from the emergency room with mild severity, patients admitted to the ward with moderate severity and critically ill patients. Our objectives in this study were: (1) to evaluate if there is an association between SARS-CoV-2 RNAemia and viral RNA load with moderate disease; (2) to evaluate if there is an association between SARSCoV-2 RNAemia and viral RNA load with critical illness; and (3) to evaluate the correlations between SARS-CoV-2 RNA load in plasma and parameters of dysregulated host responses against SARS-CoV-2.

\section{Methods \\ Study design}

A total of 250 adult patients with a positive nasopharyngeal swab polymerase chain reaction (PCR) test for SARS-CoV-2 performed at participating hospitals were recruited during the first pandemic wave in Spain from March 16th to the 15th of April 2020. The patients recruited were of three different categories. The first corresponded to patients examined at an emergency room and discharged within the first $24 \mathrm{~h}$ (outpatients group, $\mathrm{n}=50$ ). The second group were patients hospitalized to pneumology, infectious diseases or internal medicine wards (wards group, $\mathrm{n}=100$ ). Patients who required 
critical care or died during hospitalization were excluded from this group, in order to have a group of clear moderate severity. The third group corresponded to patients admitted to the ICU $(n=100)$. Patient's recruited by participating hospital are detailed in the Additional file 1. Twenty healthy blood donors were included as controls. These controls were recruited during the pandemics, in parallel to the SARS-CoV-2 infected patients, and were negative for SARS-CoV-2 IgG. This study was registered at Clinicaltrials.gov with the identification NCT04457505.

\section{Blood samples}

Plasma from blood collected in EDTA tubes samples was obtained from the three groups of patients in the first $24 \mathrm{~h}$ following admission to the emergency room, to the ward, or to the ICU, at a median collection day since disease onset of 7, 8 and 10, respectively, and also from 20 blood donors (10 men and 10 women).

\section{Biomarker profiling}

A panel of biomarkers was profiled by using the EllaSimplePlex ${ }^{\mathrm{TM}}$ immunoassay (San Jose, California, USA), informing of the following biological functions potentially altered in severe COVID-19, based in the available evidence on COVID-19 physiopathology [13] [17] and also in our previous experience on emerging infections and sepsis [18-21]: neutrophil degranulation: Lipocalin-2/NGAL, myeloperoxidase; endothelial dysfunction: ICAM-1, VCAM-1/CD106, angiopoietin-2; T cell survival and function: IL-7, Granzyme B; immunosuppression: IL-1ra, B7-H1/PD-L1, IL-10; chemotaxis: CXCL10/ IP10, CCL2; Th1 response: interleukin 1 beta, IFN- $\gamma$, IL12p70, IL-15, TNF- $\alpha$, IL-2; Th2 response: IL-4, IL-10; Th17 response: IL-6, IL-17A; granulocyte mobilization / activation: G-CSF, GM-CSF; coagulation activation: D-Dimer; acute phase reactants: ferritin (C-reactive protein and LDH were profiled in each participant hospital by their central laboratories).

\section{Detection and quantification of SARS-CoV-2 RNA in plasma} RNA was extracted from $100 \mu$ of plasma using an automated system, eMAG ${ }^{\circledR}$ from bioMérieux ${ }^{\circledR}$ (Marcy l'Etoile, France). Detection and quantification of SARSCoV-2 RNA was performed in five $\mu$ l of the eluted solution using the Bio-Rad SARS-CoV-2 ddPCR kit according to manufacturer's specifications on a QX-200 droplet digital PCR platform from the same provider. This PCR targets the $\mathrm{N} 1$ and $\mathrm{N} 2$ regions of the viral nucleoprotein gene and also the human ribonuclease (RNase) P gene using the primers and probes sets detailed in the CDC 2019 Novel Coronavirus (2019-nCoV) Real-Time RTPCR Diagnostic Panel [22]. Samples were considered positive for SARS-CoV-2 when N1 and/or N2 presented values $\geq 0.1$ copies $/ \mu \mathrm{L}$ in a given reaction. RNase $\mathrm{P}$ gene was considered positive when it presented values $\geq 0.2$ copies $/ \mu \mathrm{L}$, following manufacturer's indications. The test was only considered valid when RNase P gene was positive. Final results were given in copies of cDNA / mL of plasma. IgG specific for the nucleocapsid protein of SARS-CoV-2 was detected in $150 \mu \mathrm{l}$ of plasma using the Abbott Architect SARS-CoV-2 IgG Assay (Illinois, USA). Viral RNA and SARS-CoV-2 IgG were profiled in the same plasma sample.

\section{Statistical analysis}

For the demographic and clinical characteristics of the patients, the differences between groups were assessed using the Chi-square test / Fisher's exact test where appropriated for categorical variables. Differences for continuous variables were assessed by using the KruskalWallis test with post hoc tests adjusting for multiple comparisons. Multivariate logistic regression analysis was employed to evaluate the association between viral RNAemia and viral RNA load in plasma with severity, in the comparisons [outpatients vs ward patients] and [ward patients vs ICU patients]. Variables showing significant differences between groups in each comparison in the Kruskal-Wallis test were further introduced in the multivariate analysis as adjusting variables. The list of variables considered as potential adjusting variables were [Age (years)], [Sex (male)], [Alcoholism], [Smoker], [Drug abuse], [Cardiac disease], [Chronic vascular disease], [COPD], [Asthma], [Obesity], [Hypertension], [Dyslipidemia], [Chronic renal disease], [Chronic hepatic disease], [Neurological disease], [HIV], [Autoimmune disease], [Chronic inflammatory bowel disease], [Type 1 diabetes], [Type 2 diabetes], [Cancer], [Invasive mechanical ventilation], [Non-invasive mechanical ventilation], [SARS-CoV-2 IgG], [Temperature $\left.\left({ }^{\circ} \mathrm{C}\right)\right]$, [Systolic pressure $(\mathrm{mmHg})$ ], [Oxygen saturation (\%)], [Bilateral pulmonary infiltrate], [Glucose $(\mathrm{mg} / \mathrm{dl})]$, [Creatinine $(\mathrm{mg} / \mathrm{dl})]$, [Na $(\mathrm{mEq} / \mathrm{L})],[\mathrm{K}(\mathrm{mEq} / \mathrm{L})]$, [Platelets $\left(\right.$ cell $\left.\left.\times 10^{3} / \mu \mathrm{l}\right)\right]$, [INR], [D Dimer (pg/ml)], [LDH (UI/L)], [GPT (UI/L)], [Ferritin $(\mathrm{pg} / \mathrm{ml})]$, [CRP $(\mathrm{mg} / \mathrm{dl})]$, [Haematocrit (\%)], [Lymphocytes $\left(\right.$ cells $\left.\left./ \mathrm{mm}^{3}\right)\right]$, [Neutrophils $\left(\right.$ cells $\left./ \mathrm{mm}^{3}\right)$ ], [Monocytes $\left(\right.$ cells $\left.\left./ \mathrm{mm}^{3}\right)\right]$. Multivariate logistic regression analysis was performed using the "Enter" method, but also the backward stepwise selection method (Likelihood Ratio) was employed in each case to confirm the association between viral RNAemia and viral RNA load in plasma with disease severity ( $\operatorname{pin}<0.05$, pout $<0.10$ ), not forcing entry of these variables in the model. Correlation analysis was performed using the Spearman test applying the Bonferroni correction of the $p$ value. Variables evaluated for correlation with viral RNA load were: 
[Temperature $\left.\left({ }^{\circ} \mathrm{C}\right)\right]$, [Systolic pressure $\left.(\mathrm{mmHg})\right]$, [Oxygen saturation (\%)], [Lymphocytes $\left(\right.$ cells $\left./ \mathrm{mm}^{3}\right)$ ], [Neutrophils $\left(\right.$ cells $\left./ \mathrm{mm}^{3}\right)$ ], [Monocytes $\left(\right.$ cells $\left./ \mathrm{mm}^{3}\right)$ ], [Creatinine $(\mathrm{mg} /$ $\mathrm{dl})$ ], [LDH $(\mathrm{UI} / \mathrm{L})]$, [GPT $(\mathrm{UI} / \mathrm{L})]$, [Platelets $\left(\right.$ cell $\times 10^{3} /$ $\mu \mathrm{l})$ ], [INR], [CRP $(\mathrm{mg} / \mathrm{dl})$ ], and all the biomarkers analysed by Ella-SimplePlex. Statistical analysis was performed with IBM SPSS ${ }^{\circledR}$ version 20 (IBM, Armonk, New York, USA).

\section{Results}

\section{Clinical characteristics of the patients (Table 1)}

Patients requiring hospitalization (either general ward or ICU) were older than those patients discharged to their home from the ER. Critically ill patients were more frequently male than those in the other groups. Comorbidities of obesity, hypertension, dyslipidemia and type 2 diabetes were more commonly found in patients requiring hospitalization, with no significant differences found in the comorbidities profile between critically ill and noncritically ill hospitalized patients. Fourteen per cent of the patients in clinical wards required non-invasive mechanical ventilation, while $96 \%$ of the patients admitted to the ICU required invasive mechanical ventilation. Critically ill patients had increased glucose levels, along with higher concentration of neutrophils in blood, increased levels of ferritin and $\mathrm{C}$-reactive protein (denoting activation of the systemic inflammatory response). Increased levels of INR and D-dimers (reflecting activation of the coagulation system), as well as LDH and GPT, which levels raise as consequence of tissue and liver damage, were also observed in critically ill patients. Patients admitted to the ICU also showed a lower haematocrit, pronounced lymphopenia and lower monocyte counts at admission. ICU patients stayed longer in the hospital than ward patients, with $49 \%$ having a fatal outcome.

\section{Viral RNAemia, viral RNA load in plasma and specific SARS-Cov-2 lgG in the three groups of patients}

As depicted in Table 1, the frequency of the detection of SARS-CoV-2 viral RNA (RNAemia) was significantly higher in the critically ill patients (78\%) compared to ward patients $(27 \%)$ and outpatients $(2 \%)(p<0.001)$. Similarly, the group of critically patients showed higher viral RNA loads in plasma than either ward or outpatients $(p<0.001)$ (Table 1 and Fig. 1). Non-survivors showed the highest concentrations of viral RNA in plasma: viral RNA load (N1 region) in ICU non-survivors: 1587 copies / $\mathrm{ml}$ [10248]; viral RNA load (N1 region) in ICU survivors 574 copies / $\mathrm{mL}$ [1872] (results expressed as median [interquartile rank]); viral RNA load (N2 region) in ICU non-survivors: 2798 copies / ml [12012]; viral RNA load (N2 region) in ICU survivors 523 copies / $\mathrm{mL}$ [1478]. Patients admitted to the wards showed a significant higher frequency of viral RNAemia than outpatients, but viral RNA loads were not significantly different with the latter group (Table 1 and Fig. 1). Critically ill patients also had a higher frequency of specific SARS-CoV-2 IgG responses than the other groups $(70 \%$ in ICU compared to $52 \%$ and $49 \%$ in the outpatients and ward groups, $p<0.05$, Table 1). No significant differences were found between the group of outpatients and those admitted to the ward. The prevalence of viral RNAemia did not differ between those patients testing positive and those testing negative for SARS-CoV-2 IgG (43.8\% and 40.4\%, respectively, $p=0.586$ ), who in addition showed no differences in viral RNA load (data not shown). Patients with viral RNAemia showed no differences in the days since onset of symptoms compared to those with no viral RNAemia (8.0 days [6.0]; 8.0 days [7.2], $p=0.965$ ). In contrast, samples from patients with SARS-CoV-2 IgG were collected later since disease onset that those without SARS-CoV-2 IgG (10.0 days [7]; 7.0 days [6.0], $p=0.003$ ).

\section{Multivariate analysis to evaluate the association between viral RNAemia and viral RNA load in plasma with moderate disease and critical illness}

While the proportion of patients with viral RNAemia was higher in the wards group compared to the outpatients' group (Table 1), the multivariate analysis did not show a significant association between the presence of viral RNAemia and being hospitalized at the ward, with none of the both methods employed (Additional files 2 and 3). In contrast, when the ward group was compared with critically ill patients, a significant direct association was found between viral RNAemia and viral RNA load with critical illness, using the "Enter" method (Table 2) but also the backward stepwise selection method (Additional file 4).

\section{Correlations between viral RNA load in plasma and biological responses to SARS-CoV-2 infection}

viral RNA load in plasma (targeting either the N1 and the $\mathrm{N} 2$ regions) showed the strongest direct correlations with plasma levels of CXCL10, LDH, IL-10, IL-6, IL-15, myeloperoxidase and CCL-2 (MCP-1) and inverse correlations with lymphocytes, monocytes and $\mathrm{O} 2$ saturation (Fig. 2). These were the parameters whose levels varied the most in critically patients compared with ward and outpatient groups (Figs. 3, 4 and Additional file 5). CXCL10 was the most accurate identifier of viral RNAemia in plasma (area under the curve (AUC), [CI95\%], p) $=0.85[0.80-0.89),<0.001)$, and IL-15 was the cytokine which most accurately differentiated clinical ward patients from ICU patients (AUC: 0.82 [0.76 - 0.88],<0.001). Plasma viral RNA load also showed significant direct correlations with levels of VCAM-1, 
Table 1 Clinical characteristics of the patients

\begin{tabular}{|c|c|c|c|c|c|c|c|}
\hline & & Outpatients (1) & Ward (2) & $\operatorname{ICU}(3)$ & $\begin{array}{l}p \text { value } \\
\text { (1 vs. } 2 \text { ) }\end{array}$ & $\begin{array}{l}p \text { value } \\
\text { (1 vs. 3) }\end{array}$ & $\begin{array}{l}p \text { value } \\
\text { ( } 2 \text { vs. } 3 \text { ) }\end{array}$ \\
\hline \multirow[t]{2}{*}{ Characteristics } & Age [years, median (IQR)] & $48.50[19]$ & $64[20]$ & $66[19]$ & $<0.001$ & $<0.001$ & n.s \\
\hline & Male $[\%,(n)]$ & $46(23)$ & $50(50)$ & $64(64)$ & n.s & 0.035 & 0.046 \\
\hline \multirow[t]{19}{*}{ Comorbidities, [\% (n)] } & Alcoholism & $2(1)$ & $0(0)$ & $1(1)$ & n.s & n.s & n.s \\
\hline & Smoking & $4(2)$ & $5(5)$ & $6(6)$ & n.s & n.s & n.s \\
\hline & Drug abuse & $2(1)$ & $0(0)$ & $0(0)$ & n.s & n.s & n.a \\
\hline & Cardiac disease & $4(2)$ & $13(13)$ & $9(9)$ & n.s & n.s & n.s \\
\hline & Chronic vascular disease & $2(1)$ & $2(2)$ & $5(5)$ & n.s & n.s & n.s \\
\hline & COPD & $2(1)$ & $2(2)$ & $3(3)$ & n.s & n.s & n.s \\
\hline & Asthma & $8(4)$ & $6(6)$ & $2(2)$ & n.s & n.s & n.s \\
\hline & Obesity & $4(2)$ & $26(26)$ & $26(26)$ & 0.001 & 0.001 & n.s \\
\hline & Hypertension & $24(12)$ & $44(44)$ & $45(45)$ & 0.017 & 0.012 & n.s \\
\hline & Dyslipidemia & $16(8)$ & $41(41)$ & $34(34)$ & 0.002 & 0.021 & n.s \\
\hline & Chronic renal disease & $2(1)$ & $3(3)$ & $3(3)$ & n.s & n.s & n.s \\
\hline & Chronic hepatic disease & $2(1)$ & $0(0)$ & $3(3)$ & n.s & n.s & n.s \\
\hline & Neurological disease & $0(0)$ & $6(6)$ & $3(3)$ & n.s & n.s & n.s \\
\hline & HIV & $0(0)$ & $0(0)$ & $1(1)$ & n.a & n.s & n.s \\
\hline & Autoimmune disease & $2(1)$ & $1(1)$ & $1(1)$ & n.s & n.s & n.s \\
\hline & $\begin{array}{l}\text { Chronic inflammatory bowel } \\
\text { disease }\end{array}$ & $0(0)$ & $2(2)$ & $1(1)$ & n.s & n.s & n.s \\
\hline & Type 1 diabetes & $0(0)$ & $0(0)$ & $3(3)$ & n.a & n.s & n.s \\
\hline & Type 2 diabetes & $0(0)$ & $23(23)$ & $22(22)$ & $<0.001$ & $<0.001$ & n.s \\
\hline & Cancer & $6(3)$ & $2(2)$ & $1(1)$ & n.s & n.s & n.s \\
\hline \multirow{10}{*}{$\begin{array}{l}\text { Treatment during hospitalization, } \\
{[\%(n)]}\end{array}$} & Invasive mechanical ventilation & $0(0)$ & $0(0)$ & $96(96)$ & n.a & $<0.001$ & $<0.001$ \\
\hline & $\begin{array}{l}\text { Non-invasive mechanical ventila- } \\
\text { tion }\end{array}$ & $0(0)$ & $14(14)$ & $34(34)$ & 0.004 & $<0.001$ & 0.002 \\
\hline & Hydroxychloroquine & $77.6(38)$ & $89(89)$ & 99 (99) & n.s & $<0.001$ & 0.003 \\
\hline & Chloroquine & $4.1(2)$ & $7(7)$ & $0(0)$ & n.s & 0.042 & 0.007 \\
\hline & Corticoids & $6.7(3)$ & $29(29)$ & $85(85)$ & 0.002 & $<0.001$ & $<0.001$ \\
\hline & Azithromycin & $15.9(7)$ & $84(84)$ & $84(84)$ & $<0.001$ & $<0.001$ & n.s \\
\hline & Remdesivir & $0(0)$ & $1(1)$ & $9(9)$ & n.s & 0.029 & 0.009 \\
\hline & Tocilizumab & $0(0)$ & $13(13)$ & $33(33)$ & 0.008 & $<0.001$ & 0.001 \\
\hline & Lopinavir/ritonavir & $74(37)$ & $35(35)$ & $96(96)$ & $<0.001$ & $<0.001$ & $<0.001$ \\
\hline & Beta Interferon & $0(0)$ & $0(0)$ & $55(55)$ & n.a & $<0.001$ & $<0.001$ \\
\hline \multirow[t]{6}{*}{ Time course and outcome } & Hospital stay [days, median, (IQR)] & - & $9(6)$ & $24(19)$ & n.a & n.a & $<0.001$ \\
\hline & $\begin{array}{l}\text { Viral RNAemia } \\
{[\%(n)]}\end{array}$ & $2(1)$ & $27(27)$ & $78(78)$ & $<0.001$ & $<0.001$ & $<0.001$ \\
\hline & $\begin{array}{l}\text { Viral RNA load in plasma (N1) } \\
\text { (copies / mL, median, (IQR)) }\end{array}$ & $0(0)$ & $0(91)$ & $829(4444)$ & n.s & $<0.001$ & $<0.001$ \\
\hline & $\begin{array}{l}\text { Viral RNA load in plasma (N2) } \\
\text { (copies / mL, median, (IQR)) }\end{array}$ & $0(0)$ & $0(93)$ & 836 (4939) & n.s & $<0.001$ & $<0.001$ \\
\hline & SARS-CoV-2 lgG, [\% (n)] & $52(26)$ & $49(49)$ & $70(70)$ & n.s & 0.030 & 0.002 \\
\hline & Hospital mortality, [\% (n)] & $0(0)$ & $0(0)$ & 49(49) & n.a & $<0.001$ & $<0.001$ \\
\hline
\end{tabular}


Table 1 (continued)

\begin{tabular}{|c|c|c|c|c|c|c|c|}
\hline & & Outpatients (1) & Ward (2) & ICU (3) & $\begin{array}{l}p \text { value } \\
\text { (1 vs. 2) }\end{array}$ & $\begin{array}{l}p \text { value } \\
\text { (1 vs. 3) }\end{array}$ & $\begin{array}{l}p \text { value } \\
\text { (2 vs. 3) }\end{array}$ \\
\hline \multirow[t]{21}{*}{ Measurements at diagnosis } & Temperature $\left({ }^{\circ} \mathrm{C}\right)$ [median (IQR)] & $36.50(1.0)$ & $36.80(1.4)$ & $37.00(1.4)$ & - & - & - \\
\hline & $\begin{array}{l}\text { Systolic pressure }(\mathrm{mmHg}) \\
\text { [median (IQR)] }\end{array}$ & $120(29)$ & $126(25)$ & $120(26)$ & n.s & n.s & 0.001 \\
\hline & $\begin{array}{l}\text { Oxygen saturation (\%) [median } \\
\text { (IQR)] }\end{array}$ & $96(3)$ & $94(5)$ & $92(6)$ & 0.002 & $<0.001$ & 0.002 \\
\hline & Pulmonary infiltrate [\% (n)] & $72(36)$ & $93(93)$ & $100(100)$ & $<0.001$ & $<0.001$ & 0.007 \\
\hline & Bilateral pulmonary infiltrate [\% (n)] & $26(13)$ & $67(67)$ & $93(93)$ & $<0.001$ & $<0.001$ & $<0.001$ \\
\hline & Glucose (mg/dl) [median (IQR)] & $99.5(22)$ & $112(31)$ & $160.50(83)$ & $<0.001$ & $<0.001$ & $<0.001$ \\
\hline & Creatinine (mg/dl) [median (IQR)] & $0.84(0.18)$ & $0.91(0.33)$ & $0.88(0.57)$ & - & - & - \\
\hline & $\mathrm{Na}(\mathrm{mEq} / \mathrm{L})[$ median $(\mathrm{IQR})]$ & $138(4)$ & $138(5)$ & $138.50(7)$ & - & - & - \\
\hline & $\mathrm{K}(\mathrm{mEq} / \mathrm{L})[$ median $(\mathrm{IQR})]$ & $3.90(0.50)$ & $4.10(0.68)$ & $3.95(0.90)$ & - & - & - \\
\hline & $\begin{array}{l}\text { Platelets }\left(\text { cell } \times 10^{3} / \mu \mathrm{l}\right) \text { [median } \\
\quad(\mathrm{IQR})]\end{array}$ & 223 [97] & 207 [113] & 204 [126] & - & - & - \\
\hline & INR [median (IQR)] & $1.04(0.10)$ & $1.11(0.13)$ & $1.22(0.22)$ & 0.004 & $<0.001$ & $<0.001$ \\
\hline & D Dimer (pg/ml) [median (IQR)] & $\begin{array}{l}795,278 \\
{[828234]}\end{array}$ & $\begin{array}{l}1,597,362 \\
{[2024704]}\end{array}$ & $\begin{array}{l}6,182,104 \\
{[52690922]}\end{array}$ & $<0.001$ & $<0.001$ & $<0.001$ \\
\hline & LDH (UI/L) [median (IQR)] & $214(73)$ & $278(138)$ & $496(285)$ & 0.002 & $<0.001$ & $<0.001$ \\
\hline & GPT (UI/L) [median (IQR)] & $27(43)$ & $29(29)$ & $44(44.50)$ & n.s & 0.021 & 0.001 \\
\hline & Ferritin (pg/ml) [median (IQR)] & $\begin{array}{l}359,507 \\
{[458748]}\end{array}$ & $\begin{array}{l}523,805 \\
{[534757]}\end{array}$ & $\begin{array}{l}923,687 \\
{[1526492]}\end{array}$ & n.s & $<0.001$ & 0.002 \\
\hline & CRP (mg/dl) [median (IQR)] & $1.40(3.50)$ & $40.90(89.18)$ & $91(182.10)$ & $<0.001$ & $<0.001$ & 0.031 \\
\hline & Haematocrit (\%) [median (IQR)] & $43.15(4.72)$ & $42.50(6.50)$ & $38.15(6.48)$ & n.s & $<0.001$ & $<0.001$ \\
\hline & WBC (cells/mm³) [median (IQR)] & $6450(2815)$ & 7005 (4115) & $9145(6613)$ & n.s & $<0.001$ & 0.006 \\
\hline & $\begin{array}{l}\text { Lymphocytes (cells/mm³) } \\
\text { [median (IQR)] }\end{array}$ & $1400(805)$ & $1000(433)$ & $540(445)$ & 0.006 & $<0.001$ & $<0.001$ \\
\hline & $\begin{array}{l}\text { Neutrophils (cells/mm³) } \\
{[\text { median (IQR)] }}\end{array}$ & $4260(2625)$ & $5250(3918)$ & 8300 (5880) & n.s & $<0.001$ & $<0.001$ \\
\hline & $\begin{array}{l}\text { Monocytes (cells/mm³) } \\
\text { [median (IQR)] }\end{array}$ & $500(300)$ & $400(300)$ & $300(280)$ & n.s & $<0.001$ & $<0.001$ \\
\hline
\end{tabular}

Continuous variables are represented as [median, (interquartile range, IQR)]; categorical variables are represented as [\%, (n)]; INR, International Normalized Ratio; n.s., not significant; n.a., not applicable. COPD (Chronic obstructive pulmonary disease), HIV (Human Immunodeficiency Virus), INR (International Normalized Ratio), LDH (Lactic Acid Dehydrogenase), GPT (glutamic-pyruvate transaminase); CRP (C-reactive protein), WBC (white blood cell)

PDL-1, GM-CSF, G-CSF, neutrophil counts, IL-1ra, CRP, INR, D-dimer, TFN $\alpha$, angiopoietin-2, GPT, ICAM-1, IL-7 and ferritin (Fig. 2), with most of these mediators showing the highest variations in the critically ill patients (Figs. 3, 4 and Additional file 5).

\section{Discussion}

Our study demonstrates that the presence of SARSCoV-2-RNA in plasma is associated with critical illness in COVID-19 patients, with the strength of association being the highest in those patients with the highest viral RNA loads. This association was independent of other factors also related to disease severity. Moreover, those critically ill patients who died presented with higher viral RNA loads in plasma than those who survived. SARS-CoV-2 viral RNA was detected in the plasma of the vast majority of those COVID-19 patients admitted to the ICU (78\%). As far as we know, our study is the largest one to date using ddPCR to quantify SARS-CoV-2 RNA load in plasma from COVID-19 patients, and the only one with a multicentric design. Our results are in consonance with those from Veyer et al., who, in a pilot study using this technology, found higher viral RNA loads and a prevalence of RNA 

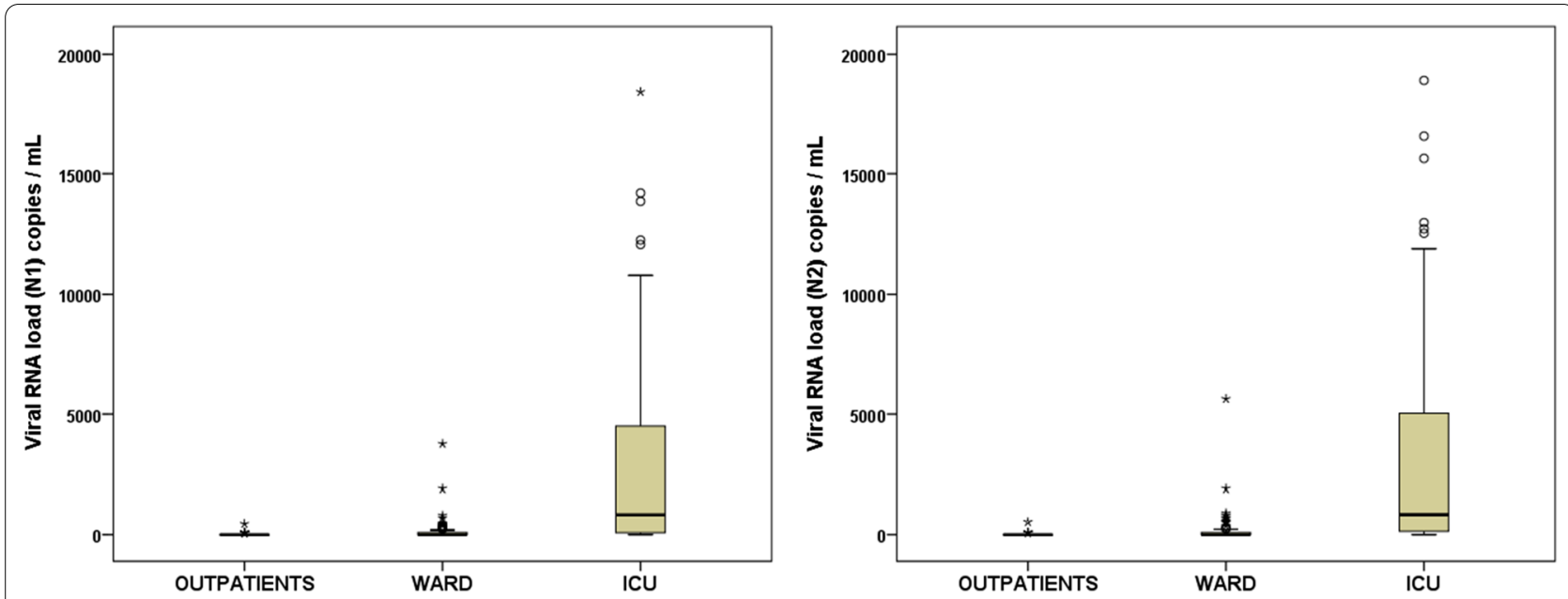

Fig. 1 Viral RNA load in plasma, targeting the N1 region (left) and the N2 region (right), in the three groups of patients. Results are provided as copies of $\mathrm{CDNA}$ per $\mathrm{mL}$ of plasma

Table 2 Multivariate logistic regression analysis comparing wards patients against critically ill patients (Enter method)

\begin{tabular}{|c|c|c|c|c|c|c|}
\hline & OR [Cl95\%] & $p$ & OR [Cl95\%] & $p$ & OR [CI95\%] & $p$ \\
\hline Sex (male) & $2.055[0.656-6.432$ & 0.216 & $1.647[0.508-5.337]$ & 0.406 & $1.608[0.500-5.166]$ & 0.425 \\
\hline Systolic pressure (mmHg) & $0.985[0.960-1.011$ & 0.253 & $0.984[0.958-1.011]$ & 0.247 & $0.984[0.957-1.012]$ & 0.261 \\
\hline O2 Saturation (\%) & $1.069[0.986-1.160]$ & 0.107 & $1.076[0.992-1.167]$ & 0.079 & $1.082[0.993-1.180]$ & 0.071 \\
\hline Bilateral pulmonary infiltrate & $2.343[0.469-11.707]$ & 0.300 & $3.088[0.566-16.852]$ & 0.193 & $3.064[0.539-17.430]$ & 0.207 \\
\hline Glucose (mg/dl) & $1.008[1.001-1.015]$ & 0.028 & $1.007[1.000-1.015]$ & 0.061 & 1.007 [0.999-1.014] & 0.070 \\
\hline INR & $1.123[0.433-2.915]$ & 0.812 & $1.245[0.469-3.305]$ & 0.661 & $1.377[0.519-3.657]$ & 0.521 \\
\hline D-dimer ( $\mathrm{pg} / \mathrm{mL})$ & $1.000[1.000-1.000]$ & 0.294 & $1.000[1.000-1.000]$ & 0.190 & 1.000 [1.000-1.000] & 0.420 \\
\hline LDH (UI/L) & $1.009[1.004-1.014]$ & 0.000 & $1.008[1.003-1.013]$ & 0.002 & $1.009[1.004-1.014]$ & 0.001 \\
\hline GPT (UI/L) & 1.005 [0.992-1.019] & 0.443 & $1.005[0.991-1.019]$ & 0.516 & $1.006[0.992-1.021]$ & 0.402 \\
\hline Ferritin $(\mathrm{pg} / \mathrm{mL})$ & $1.000[1.000-1.000]$ & 0.705 & $1.000[1.000-1.000]$ & 0.856 & $1.000[1.000-1.000]$ & 0.835 \\
\hline CRP $(\mathrm{mg} / \mathrm{dl})$ & 0.998 [0.992-1.003] & 0.420 & 0.999 [0.993-1.005] & 0.749 & 0.998 [0.993-1.004] & 0.547 \\
\hline Haematocrit (\%) & $0.770[0.676-0.877]$ & 0.000 & $0.762[0.665-0.872]$ & 0.000 & 0.737 [0.633-0.858] & 0.000 \\
\hline SARS-CoV-2 lgG (Yes) & $1.967[0.627-6.170]$ & 0.246 & $1.835[0.562-5.987]$ & 0.315 & 1.918 [0.577-6.377] & 0.288 \\
\hline Lymphocytes (cells/mm³) & 0.998 [0.996-1.000] & 0.011 & 0.998 [0.996-1.000] & 0.012 & 0.998 [0.996-0.999] & 0.010 \\
\hline Monocytes (cells/mm³) & $0.998[0.995-1.001]$ & 0.180 & $0.998[0.995-1.001]$ & 0.212 & 0.999 [0.996-1.002] & 0.463 \\
\hline Neutrophils (cells/mm³) & $1.000[1.000-1.000]$ & 0.262 & $1.000[1.000-1.000]$ & 0.326 & 1.000 [1.000-1.000] & 0.239 \\
\hline Viral RNAemia (Yes) & 3.916 [1.183-12.968] & 0.025 & - & - & - & - \\
\hline $\begin{array}{l}\text { Viral RNA load (N1) } \\
\text { in plasma, log (copies/mL) }\end{array}$ & - & - & 1.962 [1.244-3.096] & 0.004 & - & - \\
\hline $\begin{array}{l}\text { Viral RNA load (N2) } \\
\text { in plasma, log (copies/mL) }\end{array}$ & - & - & - & - & $2.229[1.382-3.595]$ & 0.001 \\
\hline
\end{tabular}

The association between viral RNAemia or viral RNA load targeting the N1 region, or viral RNA load targeting the N2 region with critical illness was evaluated adjusting by major confounding factors

viremia of $88 \%$ in twenty six COVID-19 patients who were critically ill [16]. The results are also in agreement with those of Hagman et al., who, using standard RT-PCR technology, found that the presence of SARSCoV-2 RNA in serum at hospital admission was associated with a seven-fold increased risk of critical disease and an eight-fold increased risk of death in a cohort of 167 patients hospitalized for COVID-19 [23].

Although our study did not determine if the presence of viral RNA in plasma reflects the presence of live virus in peripheral blood, the association found between the presence and concentration of viral RNA in plasma 


\begin{tabular}{|c|c|c|c|}
\hline \multirow[b]{2}{*}{ Mediator } & \multicolumn{2}{|c|}{$\begin{array}{l}\text { Correlation coefficients } \\
\qquad(p<0.0012)\end{array}$} & \multirow[b]{2}{*}{ Biological implications } \\
\hline & $\begin{array}{l}\text { VIRAL RNA LOAD } \\
\text { (N1) (copies/mL) }\end{array}$ & $\begin{array}{l}\text { VIRAL RNA LOAD } \\
\text { (N2) (copies/mL) }\end{array}$ & \\
\hline CXCL10 & & & Chemotaxis of T cells \\
\hline LDH (UI/L) & & & Tissue damage \\
\hline IL-10 (pg/mL) & & & Immunosupression / immunomodulation \\
\hline $\mathrm{IL}-6$ (pg/mL) & & & Inflammation / Induction of Th17 adaptive immunity \\
\hline IL-15 (pg/mL) & & & NK cell activation \\
\hline Myeloperoxidase $(\mathrm{pg} / \mathrm{mL})$ & & & Neutrophil degranulation \\
\hline CCL-2 (MCP-1) (pg/mL) & & & Chemotaxis of monocytes \\
\hline VCAM-1 (pg/mL) & & & Endothelial dysfunction \\
\hline PDL-1 (pg/mL) & & & Immunosupression / immunomodulation \\
\hline GM-CSF (pg/mL) & & & Neutrophils and monocytes mobilization and activation \\
\hline G-CSF $(\mathrm{pg} / \mathrm{mL})$ & & & Neutrophils mobilization and activation \\
\hline Neutrophils (cells/mm3) & & & Innate immunity enhancement \\
\hline IL-1ra (pg/mL) & & & Immunosupression / immunomodulation \\
\hline CRP (mg/dl) & & & Inflammation (acute phase reactant) \\
\hline INR & & & Coagulation activation \\
\hline DDIMER $(\mathrm{pg} / \mathrm{mL})$ & & & Coagulation activation \\
\hline TFN $\alpha(p g / m L)$ & & & Inflammation - induction of Th1 adaptive immunity \\
\hline Angiopoietin-2 & & & Endothelial dysfunction \\
\hline GPT (UI/L) & & & Liver damage \\
\hline ICAM-1 (pg/mL) & & & Endothelial dysfunction \\
\hline IL-7 (pg/mL) & & & Lymphopoiesis and lymphocyte survival \\
\hline Ferritin $(\mathrm{pg} / \mathrm{mL})$ & & & Inflammation (acute phase reactant) \\
\hline Oxygen saturation (\%) & & & Respiratory failure \\
\hline Monocytes (cells/mm3) & & & Defective antigen presentation / phagocytosis \\
\hline Lymphocytes (cells/mm3) & & & Adaptive immunity dysfunction \\
\hline
\end{tabular}

Fig. 2 Heat map representing the Spearman correlation coefficients between viral RNA load in plasma targeting the N1 and the N2 regions and representative indicators of host dysregulated response

and critical illness suggests that viral replication is more robust in severe COVID-19, and/or that critically ill patients with this disease are not able to control viral replication. This notion is further supported by the correlations found in our study between viral RNA load in plasma and hypercytokinemia involving CXCL10, IL-10, CCL2, IL-6 and IL-15, where the levels of these cytokines were the highest in patients with critical illness. The correlation between viral RNA load and higher levels of cytokines has also been described in the severe infections caused by $\mathrm{H} 5 \mathrm{~N} 1$ and pandemic $\mathrm{H} 1 \mathrm{~N} 1$ influenza strains [24] [25]. Active viral replication stimulates the secretion of cytokines by the recognition of viral RNA by endosomal receptors such as toll like receptor 7 (TLR7) in human plasmacytoid dendritic cells and B cells, or TLR8 in myeloid cells [26]. While the elevation of CXCL10, IL-10, CCL2, IL-6 has been extensively documented in severe COVID-19 [9, 10], our work demonstrates a clear correlation between these cytokines and plasma viral load. Furthermore, we report for the first time a major role of IL-15 in severe COVID-19. High levels of IL-15 in critically ill patients with high SARS-CoV-2 RNA load in plasma could be an attempt to stimulate Natural Killer cells to fight the virus [27]. We previously demonstrated that high levels of IL-15, along with IL-6, constituted a signature of critical illness in H1N1 pandemic influenza infection [20].

Viral RNA load correlated with higher levels of myeloperoxidase in plasma, which were the highest in those patients admitted to the ICU. This is a marker of neutrophil degranulation and a potent tissue damage factor which has been proposed to play a role in the pathogenesis of ARDS secondary to influenza, by mediating claudin alteration on endothelial tight junctions, eventually leading to protein leakage and viral spread [28]. In this regard, the correlation found between viral RNA load in plasma and higher levels of LDH and GPT could suggest a direct or indirect role of viral replication in mediating tissue destruction in COVID-19.

Interesting, but less robust, direct correlations were found between viral RNA load in plasma with GM-CSF and neutrophil counts in blood, further reinforcing the 

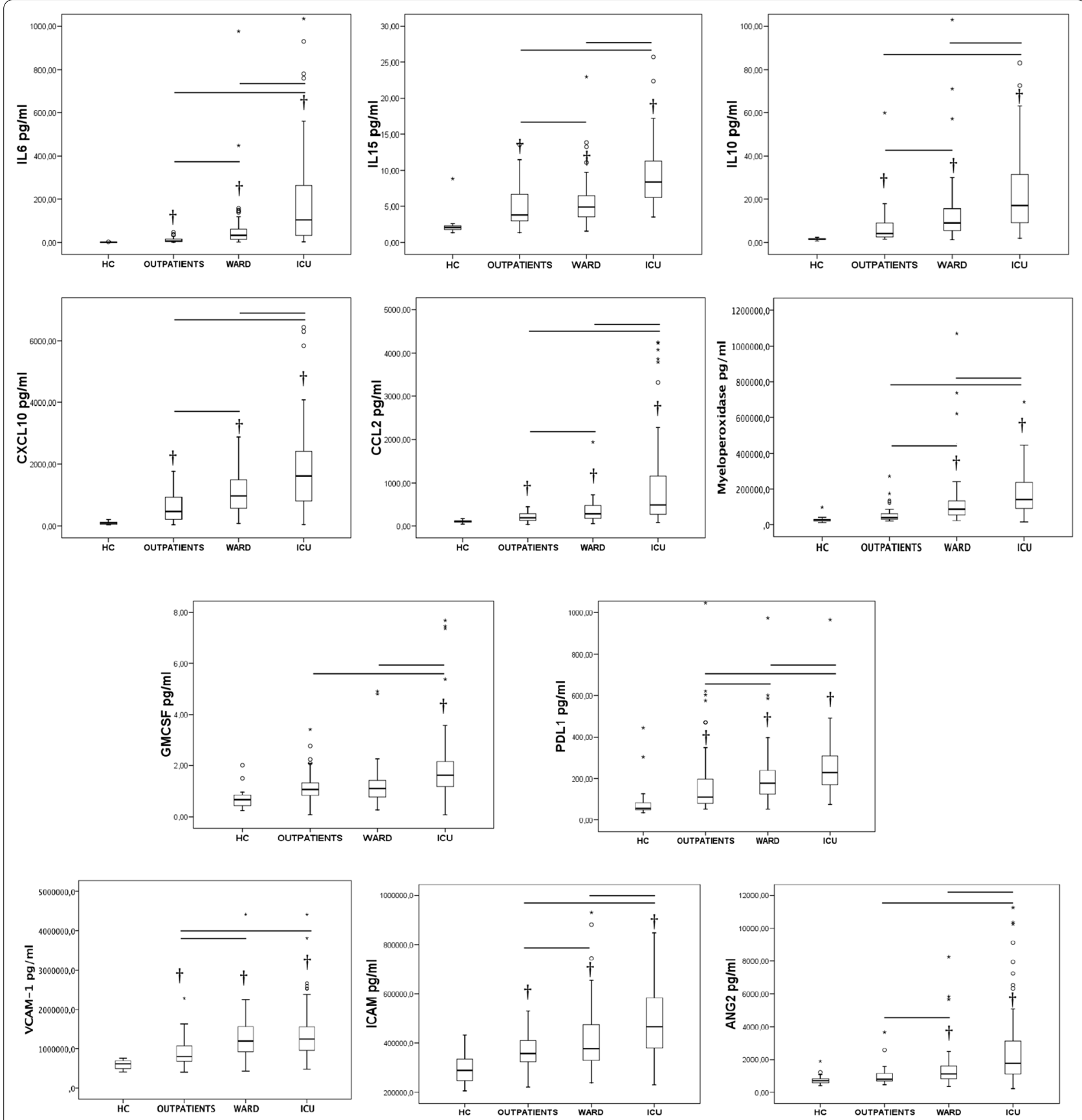

Fig. 3 Levels of laboratory parameters indicating host dysregulated response across groups. † indicates significant difference with the healthy control and the bars significant differences between the other groups

role of neutrophil mediated responses in the pathogenesis of severe COVID-19. The direct correlation with soluble PDL-1 is also relevant, since this is the ligand of the inhibitory co-receptor PD1 on T cells, which activation induces anergy of T lymphocytes [29]. This finding reinforces the potential role of immune checkpoint inhibitors in severe COVID-19 [30]. In turn, the association found between viral RNA load in plasma and three mediators of endothelial dysfunction (VCAM-1, angiopoietin-2 and ICAM-1), and with coagulation activation 

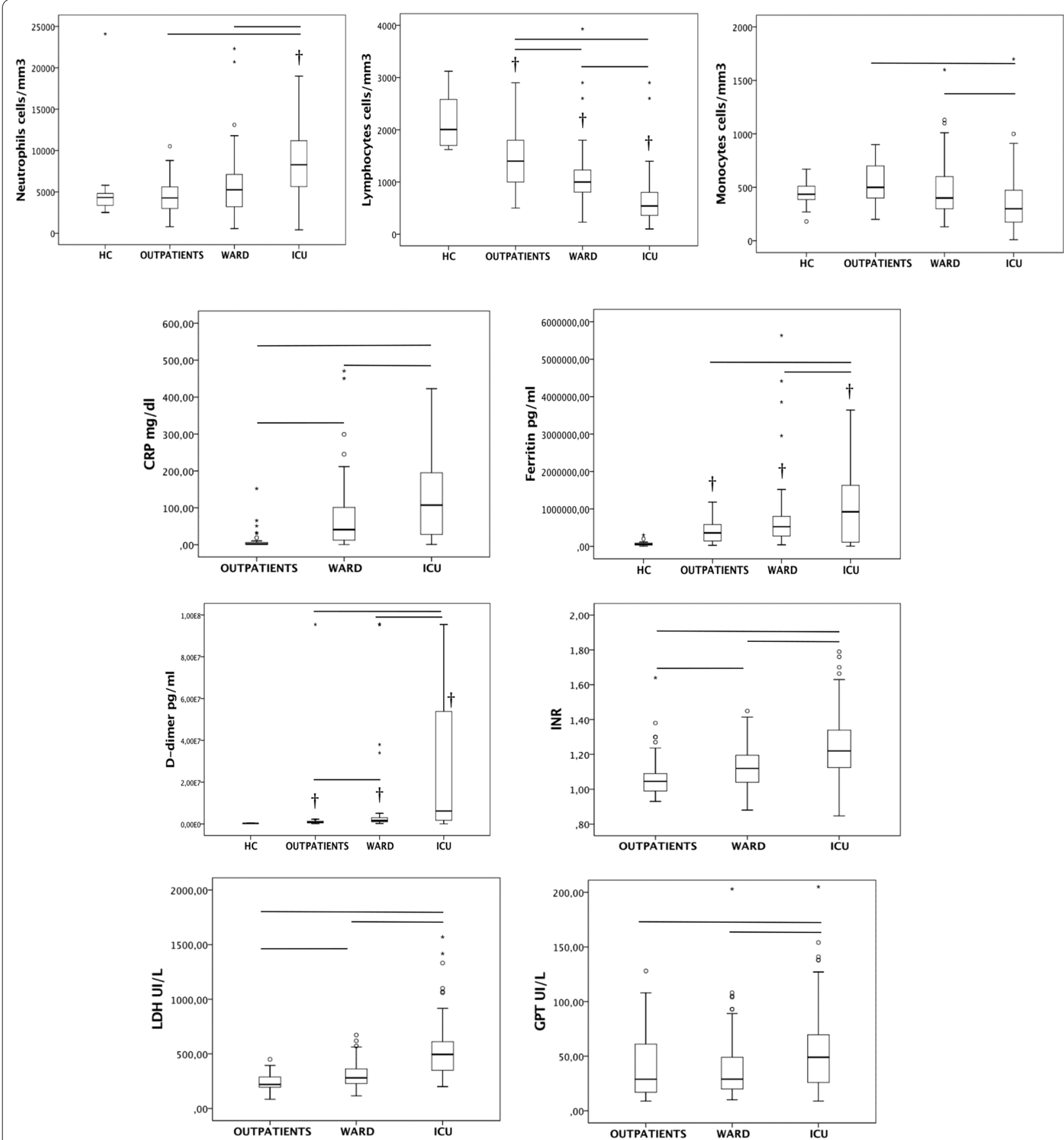

Fig. 4 Levels of laboratory parameters indicating host dysregulated response across groups. † indicates significant difference with the healthy control and the bars significant differences between the other groups

markers (D-dimers and INR prolongation) suggests a potential virally linked mechanism in the pathogenesis of endotheliitis and thrombosis in COVID-19 disease [7]. Finally, the correlation with the acute phase reactants CRP and ferritin suggests a connection between shedding of genomic material of the virus to the blood and the induction of a systemic inflammatory response which is observed in those patients needing critical care.

The strongest inverse correlations found in our study were between SARS-CoV-2 RNA load in plasma and lymphocyte and monocyte counts in peripheral blood, for which critically ill patients showed the lowest values. 


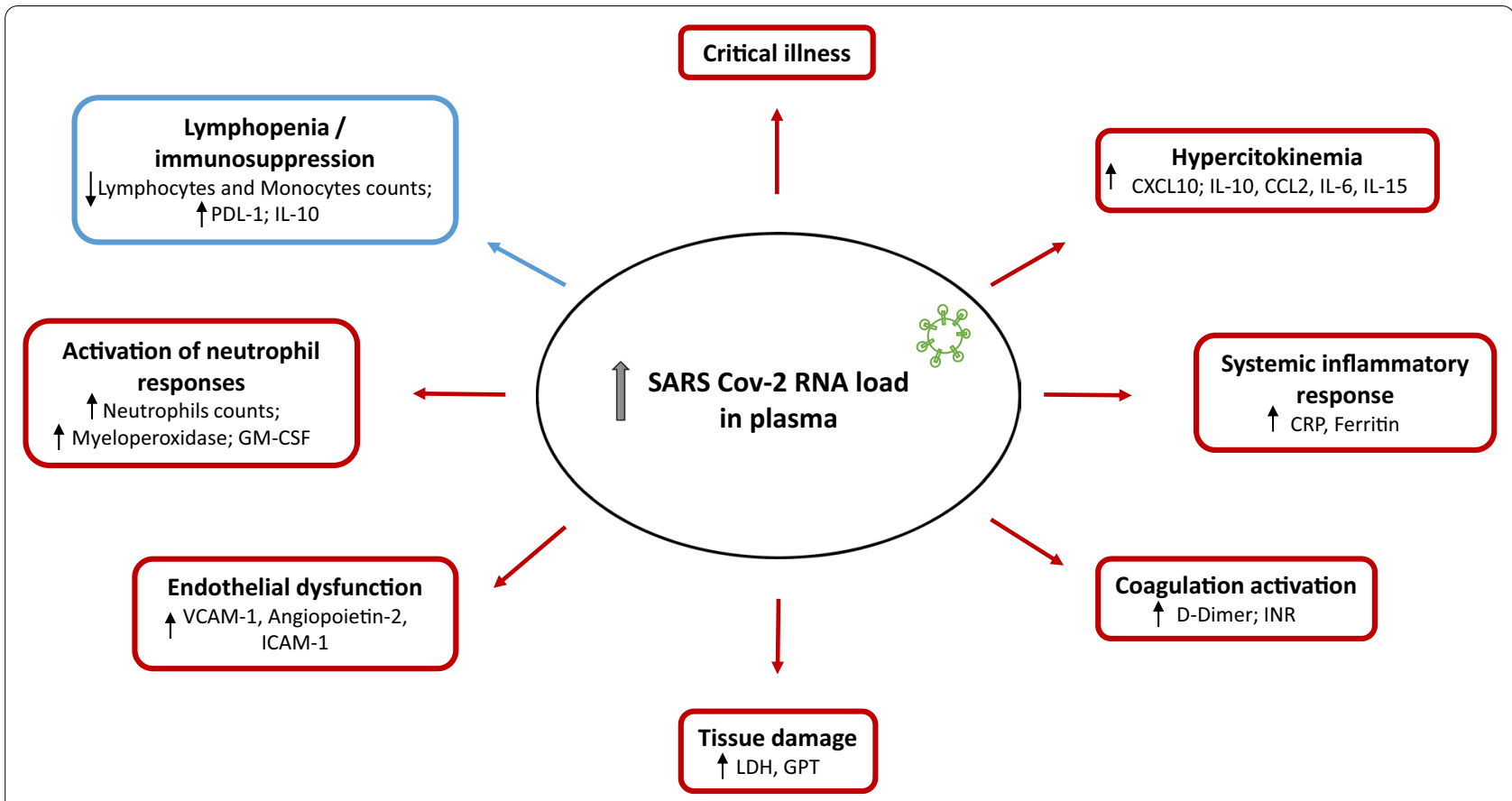

Fig. 5 Integrative model depicting the correlations found between the indicators of host dysregulated responses and SARS-CoV-2 RNA load in plasma

Active viral replication could be a precipitating event in the pathogenesis of lymphopenia and monocytopenia in severe COVID-19 patients [11,31], by mediating direct cytopathic actions or stimulating the migration of these cells to the extravascular space to reach the infected tissues [32].

A limitation of our work is its observational nature, which precludes to infer causality. Nonetheless, the observed associations could serve as hypothesis generators, leading to the development of animal models to confirm the potential link between SARS-CoV-2 replication and the dysregulated host responses observed in severe COVID-19.

\section{Conclusion}

The presence of SARS-CoV-2 RNA in plasma is associated with critical illness in patients with COVID-19. The strength of this association increases with viral RNA load in plasma, which in turn correlates with key signatures of dysregulated host response in COVID-19 (Fig. 5). Our findings suggest a major role of uncontrolled viral replication in the pathogenesis of this disease. Assessment of viral RNAemia and viral RNA load in plasma could be useful to early detect those patients at risk of clinical deterioration, to assess response to treatment and to predict disease outcome.

\section{Supplementary information}

Supplementary information accompanies this paper at https://doi. org/10.1186/s13054-020-03398-0.

Additional file 1. Recruited patients in each hospital.

Additional file 2. Multivariate logistic regression analysis comparing outpatients against wards patients (Enter method). The association between viral RNAemia with hospitalization at the wards was evaluated adjusting by major confounding factors.

Additional file 3. Multivariate logistic regression analysis comparing outpatients against wards patients (backward stepwise selection method/ Likelihood Ratio). The association between viral RNAemia with hospitalization at the wards was evaluated adjusting by major confounding factors, but it was not selected in the final model.

Additional file 4. Multivariate logistic regression analysis comparing wards patients against ICU patients (backward stepwise selection method/Likelihood Ratio). The association between viral RNAemia and viral RNA load with critical illness was evaluated adjusting by major confounding factors.

Additional file 5. Laboratory parameters levels across groups.

\section{Abbreviations}

SARS-CoV-2: Severe acute Respiratory Syndrom-Coronavirus-2; LDH: Lactate dehydrogenase; G-CSF: Granulocyte colony-stimulating factor; TLR: Toll like receptor.

\section{Acknowledgements}

We thank SEIMC-GESIDA Foundation for the scientific sponsoring of this project. We thank also the "Biobanco del Centro de Hemoterapia y Hemodonación de Castilla y León", which provided the plasma simples used in the healthy control group. 


\section{Authors' contribution}

JFBM, DJK, JB, RF, FB, AT and RM designed the study. JFBM and DJK wrote the manuscript and interpreted the data. RA coordinated the clinical study and drafted the figures. MGR, DM, PR, FPG, LT, RLI, EB, CA, JMG, JR, RM, MIF, GM, MGE, DC, FDC, JFR, WT, PGJ, GR, IM, EG,IM, SP, SM, PGO, JAC, TRA, CP, JAB, $G R, R H, J B, P E, R C, J A, J G B, N M, N B L, L J V, B F C$ and MAM recruited the patients and /or collected the clinical data. MDG, AO, RO, LMR and JME performed the assays for the detection of SARS-CoV-2 IgG and viremia. APT, CD and AO developed the $\mathrm{ddPCR}$ works; $C D$ and NJ profiled the immunological mediators. SR, AMF and MMF developed the statistical analysis and drafted the figures. AAK, ATO, AM and LF performed the literature search. All authors have read and approved the final manuscript.

\section{Funding}

This work was supported by awards from the Canadian Institutes of Health Research, the Canadian 2019 Novel Coronavirus (COVID-19) Rapid Research Funding initiative (CIHR OV2 - 170357), Research Nova Scotia (DJK), Atlantic Genome/Genome Canada (DJK), Li-Ka Shing Foundation (DJK), Dalhousie Medical Research Foundation (DJK), the "Subvenciones de concesión directa para proyectos y programas de investigación del virus SARS-CoV2, causante del COVID-19", FONDO-COVID19, Instituto de Salud Carlos III (COV20/00110, CIBERES, 06/06/0028), (AT) and finally by the "Convocatoria extraordinaria y urgente de la Gerencia Regional de Salud de Castilla y León, para la financiación de proyectos de investigación en enfermedad COVID-19" (GRS COVID 53/A/20) (CA). DJK is a recipient of the Canada Research Chair in Translational Vaccinology and Inflammation. APT was funded by the Sara Borrell Research Grant CD018/0123 funded by Instituto de Salud Carlos III and co-financed by the European Development Regional Fund (A Way to Achieve Europe programme). The funding sources did not play any role neither in the design of the study and collection, not in the analysis, in the interpretation of data or in writing the manuscript.

\section{Availability of data and materials}

The datasets generated and/or analysed during the current study are not publicly available since they are still under elaboration for publication by the authors but are available from the corresponding author on reasonable request.

\section{Ethics approval and consent to participate}

The study was approved by the Committee for Ethical Research of the coordinating institution, "Comite de Etica de la Investigacion con Medicamentos del Area de Salud de Salamanca", code PI 202003 452. Informed consent was obtained orally when clinically possible. In the remaining cases, the informed consent waiver was authorized by the Ethics committee.

\section{Consent for publication}

Not applicable.

\section{Competing interests}

The authors declare that they have no competing interests.

\section{Author details}

${ }^{1}$ Group for Biomedical Research in Sepsis (BioSepsis), Instituto de Investigación Biomédica de Salamanca, (IBSAL), Paseo de San Vicente, 58-182, 37007 Salamanca, Spain. ${ }^{2}$ Hospital Universitario Río Hortega, Calle Dulzaina, 2, 47012 Valladolid, Spain. ${ }^{3}$ Centro de Investigación Biomédica en Red en Enfermedades Respiratorias (CIBERES), Instituto de Salud Carlos III, Av. de Monforte de Lemos, 3-5, 28029 Madrid, Spain. ${ }^{4}$ Department of Laboratory Medicine, Hospital General Universitario Gregorio Marañón, Calle del Dr. Esquerdo, 46, 28007 Madrid, Spain. ${ }^{5}$ Department of Medicine, Faculty of Medicine, Universidad Complutense de Madrid, Plaza de Ramón y Cajal, s/n, 28040 Madrid, Spain. ${ }^{6}$ Emergency Department, Hospital General Universitario Gregorio Marañón, Calle del Dr. Esquerdo, 46, 28007 Madrid, Spain. ${ }^{7}$ Microbiology Service, Hospital Universitario Rio Hortega, Calle Dulzaina, 2, 47012 Valladolid, Spain. ${ }^{8}$ Viral Infection and Immunity Unit, Centro Nacional de Microbiología, Instituto de Salud Carlos III, Ctra. de Pozuelo, 28, 28222 Majadahonda, Spain. ${ }^{9}$ Hospital Universitario Infanta Leonor, Av. Gran Vía del Este, 80, 28031 Madrid, Spain. ${ }^{10}$ Servicio de Microbiología Clínica, Hospital Universitario Príncipe de Asturias, Carr. de Alcalá, s/n, 28805 Madrid, Spain. ${ }^{11}$ Intensive Care Unit, Hospital Universitario Rio Hortega, Calle Dulzaina, 2, 47012 Valladolid, Spain. ${ }^{12}$ Emergency Department, Hospital Universitario
Rio Hortega, Calle Dulzaina, 2, 47012 Valladolid, Spain. ${ }^{13}$ Intensive Care Unit, Hospital Clínico Universitario de Valladolid, Av. Ramón y Cajal, 47003 Valladolid, Spain. ${ }^{14}$ Department of Anesthesiology, Facultad de Medicina de Valladolid, Av. Ramón y Cajal, 47005 Valladolid, Spain. ${ }^{15}$ Anesthesiology and Reanimation Service, Hospital Universitario Rio Hortega, Calle Dulzaina, 2, 47012 Valladolid, Spain. ${ }^{16}$ Intensive Care Unit, Hospital General Universitario Gregorio Marañón, Calle del Dr. Esquerdo, 46, 28007 Madrid, Spain. ${ }^{17}$ Microbiology Service, Hospital Clinico Universitario de Valladolid, Av. Ramón y Cajal, 47003 Valladolid, Spain. ${ }^{18}$ Pulmonology Service, Hospital Universitario y Politécnico de La Fe, Avinguda de Fernando Abril Martorell, 106, 46026 Valencia, Spain. ${ }^{19}$ Clinical Microbiology Department, Complejo Asistencial Universitario de León, Calle Altos de Nava, s/n, 24001 León, Spain. ${ }^{20}$ Microbiology Service, Hospital Universitario de Burgos, Av. Islas Baleares, 3, 09006 Burgos, Spain. ${ }^{21}$ Intensive Care Unit, Complejo Asistencial Universitario de León, Calle Altos de nava, s/n, 24001 León, Spain. ${ }^{22}$ Pneumology Service, Hospital Universitario Río Hortega/ Biomedical Engineering Group, Universidad de Valladolid, Calle Dulzaina, 2, 47012 Valladolid, Spain. ${ }^{23}$ Intensive Care Unit, Hospital Universitario de Burgos, Av. Islas Baleares, 3, 09006 Burgos, Spain. ${ }^{24}$ Clinical Analysis Service. Hospital, Clínico Universitario de Valladolid, Av. Ramón y Cajal, 47003 Valladolid, Spain. ${ }^{25}$ Department of Microbiology and Immunology, Faculty of Medicine, Canadian Center for Vaccinology CCFV, Dalhousie University, Halifax, NS B3H 4R2, Canada. ${ }^{26}$ Laboratory of Immunity, Shantou University Medical College, 22 Xinling Rd., Jinping, Shantou, Guangdong, China. ${ }^{27}$ Department of Cardiovascular Surgery, Hospital Clínico Universitario de Valladolid, Av. Ramón y Cajal, 47003 Valladolid, Spain. ${ }^{28}$ Infectious Diseases Clinic, Internal Medicine Department, Hospital Universitario Río Hortega, Calle Dulzaina, 2, 47012 Valladolid, Spain. ${ }^{29}$ Department of Pulmonology, Hospital Clinic de Barcelona, Institut D Investigacions August Pi I Sunyer (IDIBAPS), Universidad de Barcelona, Carrer del Rosselló, 149, 08036 Barcelona, Spain. ${ }^{30}$ Intensive Care Department, Vall d'Hebron Hospital Universitari, SODIR Research Group, Vall d'Hebron Institut de Recerca, Passeig de la Vall d'Hebron, 119, 08035 Barcelona, Spain. ${ }^{31}$ Respiratory Department, Institut Ricerca Biomedica de Lleida, Av. Alcalde Rovira Roure, 80, 25198 Lleida, Spain.

Received: 3 September 2020 Accepted: 18 November 2020

Published online: 14 December 2020

\section{References}

1. COVID-19 Dashboard by the Center for Systems Science and Engineering (CSSE) at Johns Hopkins University (JHU) [Internet]. https://coronaviru s.jhu.edu/map.html

2. Guan W-J, Ni Z-Y, Hu Y, Liang W-H, Ou C-Q, He J-X, et al. Clinical characteristics of coronavirus disease 2019 in China. N Engl J Med. 2020;382:1708.

3. Cevik M, Bamford CGG, Ho A. COVID-19 pandemic: a focused review for clinicians. Clin Microbiol Inf. 2020;26:842-7.

4. Zhang W, Du R-H, Li B, Zheng X-S, Yang X-L, Hu B, et al. Molecular and serological investigation of 2019-nCoV infected patients: implication of multiple shedding routes. Emerg Microbes Inf. 2020;9:386-9.

5. Chen X, Zhao B, Qu Y, Chen Y, Xiong J, Feng Y, et al. Detectable Serum Severe Acute Respiratory Syndrome Coronavirus 2 Viral Load (RNAemia) Is Closely Correlated With Drastically Elevated Interleukin 6 Level in Critically III Patients With Coronavirus Disease 2019. Clin Infect Dis [Internet]. [cited $2020 \mathrm{Jul}$ 6]; https://academic.oup.com/cid/article/doi/https://doi. org/10.1093/cid/ciaa449/5821311

6. Zheng S, Fan J, Yu F, Feng B, Lou B, Zou Q, et al. Viral load dynamics and disease severity in patients infected with SARS-CoV-2 in Zhejiang province, China, January-March 2020: retrospective cohort study. BMJ. 2020;369:m1443.

7. Varga Z, Flammer AJ, Steiger P, Haberecker M, Andermatt R, Zinkernagel AS, et al. Endothelial cell infection and endotheliitis in COVID-19. Lancet. 2020;395:1417-8.

8. Li H, Liu L, Zhang D, Xu J, Dai H, Tang N, et al. SARS-CoV-2 and viral sepsis: observations and hypotheses. Lancet. 2020;395:1517-20.

9. Leisman DE, Ronner L, Pinotti R, Taylor MD, Sinha P, Calfee CS, et al. Cytokine elevation in severe and critical COVID-19: a rapid systematic review, meta-analysis, and comparison with other inflammatory syndromes. The Lancet Respiratory Medicine [Internet]. Elsevier; 2020 [cited 2020 Oct 21];0. https://www.thelancet.com/journals/lanres/article/PIIS2 213-2600(20)30404-5/abstract 
10. Laing AG, Lorenc A, Barrio DMD, I, Das A, Fish M, Monin L, et al. A dynamic COVID-19 immune signature includes associations with poor prognosis. Nat Med. 2020;26:1623.

11. Bao J, Li C, Zhang K, Kang H, Chen W, Gu B. Comparative analysis of laboratory indexes of severe and non-severe patients infected with COVID-19. Clin Chim Acta. 2020;509:180-94.

12. Hupf J, Mustroph J, Hanses F, Evert K, Maier LS, Jungbauer CG. RNAexpression of adrenomedullin is increased in patients with severe COVID19. Crit Care. 2020:24:527.

13. McGonagle D, O'Donnell JS, Sharif K, Emery P, Bridgewood C. Immune mechanisms of pulmonary intravascular coagulopathy in COVID-19 pneumonia. Lancet Rheumatol. 2020;2:e437-45.

14. Yang L, Liu S, Liu J, Zhang Z, Wan X, Huang B, et al. COVID-19: immunopathogenesis and Immunotherapeutics. Signal Transduct Target Ther. 2020;5:128.

15. Hogan CA, Stevens BA, Sahoo MK, Huang C, Garamani N, Gombar S, et al. High frequency of SARS-COV-2 RNAemia and association with severe disease. Clin Infect Dis. 2020;2020:1054.

16. Veyer D, Kernéis S, Poulet G, Wack M, Robillard N, Taly V, et al. Highly sensitive quantification of plasma SARS-CoV-2 RNA shelds light on its potential clinical value. Clin Infect Dis. 2020;2020:1196.

17. Vabret N, Britton GJ, Gruber C, Hegde S, Kim J, Kuksin M, et al. Immunology of COVID-19: current state of the science. Immunity. 2020;52:910-41.

18. Cameron MJ, Ran L, Xu L, Danesh A, Bermejo-Martin JF, Cameron CM, et al. Interferon-mediated immunopathological events are associated with atypical innate and adaptive immune responses in patients with severe acute respiratory syndrome. J Virol. 2007;81:8692-706.

19. Cameron MJ, Bermejo-Martin JF, Danesh A, Muller MP, Kelvin DJ. Human immunopathogenesis of severe acute respiratory syndrome (SARS). Virus Res. 2008;133:13-9.

20. Bermejo-Martin JF, Ortiz de Lejarazu R, Pumarola T, Rello J, Almansa R, Ramírez $\mathrm{P}$, et al. Th1 and Th17 hypercytokinemia as early host response signature in severe pandemic influenza. Crit Care. 2009;13:201.

21. Rubio I, Osuchowski MF, Shankar-Hari M, Skirecki T, Winkler MS, Lachmann $G$, et al. Current gaps in sepsis immunology: new opportunities for translational research. Lancet Infect Dis. 2019;19:e422-36.

22. CDC. Information for Laboratories about Coronavirus (COVID-19) [Internet]. Centers for Disease Control and Prevention. 2020 [cited 2020 Oct
14]. https://www.cdc.gov/coronavirus/2019-ncov/lab/rt-pcr-panel-prime r-probes.html

23. Hagman K, Hedenstierna M, Gille-Johnson P, Hammas B, Grabbe M, Dillner J, et al. SARS-CoV-2 RNA in serum as predictor of severe outcome in COVID-19: a retrospective cohort study. Clin Infect Dis. 2020;2020:1285.

24. de Jong MD, Simmons CP, Thanh TT, Hien VM, Smith GJD, Chau TNB, et al. Fatal outcome of human influenza $A(\mathrm{H} 5 \mathrm{~N} 1)$ is associated with high viral load and hypercytokinemia. Nat Med. 2006;12:1203-7.

25. Almansa R, Anton A, Ramirez P, Martin-Loeches I, Banner D, Pumarola $\mathrm{T}$, et al. Direct association between pharyngeal viral secretion and host cytokine response in severe pandemic influenza. BMC Infect Dis. 2011;11:232.

26. Birra D, Benucci M, Landolfi L, Merchionda A, Loi G, Amato P, et al. COVID 19: a clue from innate immunity. Immunol Res. 2020;68:161-8.

27. Perera P-Y, Lichy JH, Waldmann TA, Perera LP. The role of interleukin-15 in inflammation and immune responses to infection: implications for its therapeutic use. Microbes Infect. 2012;14:247-61.

28. Sugamata R, Dobashi H, Nagao T, Yamamoto K-I, Nakajima N, Sato Y, et al. Contribution of neutrophil-derived myeloperoxidase in the early phase of fulminant acute respiratory distress syndrome induced by influenza virus infection. Microbiol Immunol. 2012;56:171-82.

29. Venet F, Monneret G. Advances in the understanding and treatment of sepsis-induced immunosuppression. Nat Rev Nephrol. 2018;14:121-37.

30. Remy KE, Brakenridge SC, Francois B, Daix T, Deutschman CS, Monneret G, et al. Immunotherapies for COVID-19: lessons learned from sepsis. Lancet Respir Med. 2020;8:946.

31. Bermejo-Martin JF, Almansa R, Menendez R, Mendez R, Kelvin DJ, Torres A. Lymphopenic community acquired pneumonia as signature of severe COVID-19. J Inf. 2020;80:23.

32. Monneret G, Cour M, Viel S, Venet F, Argaud L. Coronavirus disease 2019 as a particular sepsis: a 2-week follow-up of standard immunological parameters in critically ill patients. Intensive Care Med. 2020;46:1764-5.

\section{Publisher's Note}

Springer Nature remains neutral with regard to jurisdictional claims in published maps and institutional affiliations.
Ready to submit your research? Choose BMC and benefit from:

- fast, convenient online submission

- thorough peer review by experienced researchers in your field

- rapid publication on acceptance

- support for research data, including large and complex data types

- gold Open Access which fosters wider collaboration and increased citations

- maximum visibility for your research: over $100 \mathrm{M}$ website views per year

At BMC, research is always in progress.

Learn more biomedcentral.com/submissions 